\section{Light Acclimatization Potential of Leea coccinia and Leea rubra Grown under Low Light Flux}

\author{
J.M. Sarracino ${ }^{1}$, R. Merritt ${ }^{2}$, and C.K. Chin $^{2}$ \\ Department of Horticulture, Rutgers University Cook College, New \\ Brunswick, NJ 08903
}

Additional index words. Ficus benjamina, light compensation point, photosynthesis, respiration

\begin{abstract}
Two foliage plant species, Leea coccinia L. and Leea rubra L., exhibited lower light compensation points and faster rates of acclimatization than Ficus benjamina L. when moved from full sun to dense shade, i.e., from 15.7 to 0.26 or 0.09 mol $\cdot \mathrm{m}^{-2} \cdot$ day $^{-1}$. Light compensation points were reduced up to $75 \%$ for $L$. coccinia and $71 \%$ for $L$. rubra after 25 days under these conditions. Uptake of $\mathrm{CO}_{2}$ increased from $65 \%$ to $179 \%$ and $34 \%$ to $118 \%$ for $L$. coccinia and $L$. rubra, respectively, while respiration rates were reduced from $73 \%$ and $76 \%$ to $59 \%$ to $68 \%$, respectively. Ficus benjamina plants died under similar conditions.
\end{abstract}

There has been a dramatic increase in the use of large foliage plants in indoor living and working spaces. However, there are few large plant species suitable for interiors, the predominant species currently being Ficus benjamina. Plants for interior use must be able to acclimatize to interior environmental conditions. Two attractive species that may be suitable for use as interior plants are Leea coccinia and L. rubra, both multi-stemmed, bi- and tri-pinnately compound leaved plants that may attain heights of $4 \mathrm{~m}$ (Liberty Hyde Bailey Hortorium, 1977).

Plants in general have the ability to adjust to changes in environmental conditions by undergoing morphological and physiological changes including in leaf morphology, chloroplast structure, stomatal resistance, ratio of chloroplast components, and capacity of chloroplast reactions (Boardman, 1977). The capacity to acclimate varies with plant species and genotype. Indoor and outdoor environments often differ in many respects, most notably in temperature, humidity, and light intensity. The ability of foliage plants to acclimatize rapidly to dim light is vital to their survival and use (Collard et al., 1977; Conover and Poole, 1975; Fails et al., 1982b; Larson, 1979). The rate of acclimatization of four species of tropical foliage plants over 15 weeks from full sun to low light intensity

Received for publication 30 Aug. 1991. Accepted for publication 27 Dec. 1991. New Jersey Agricultural Experiment Station, Publication no. D03130-4-92, supported by state funds. We acknowledge and thank Karen Haboush for her assistance in the collection of data and Douglas Eberhardt for his assistance in the statistical analyses. The cost of publishing this paper was defrayed in part by the payment of page charges Under postal regulations, this paper therefore must be hereby marked advertisement solely to indicate this fact.

${ }^{1}$ Technology Licensing Assistant, Rutgers Univ., New Jersey Agricultural Experiment Station, 377 Hoes Lane, Piscataway, NJ 08855.

${ }^{2}$ Professor. $\left(4.9 \mathrm{~mol} \cdot \mathrm{m}^{-2} \cdot\right.$ day $\left.^{-1}\right)$ indicated that species possessed different rates of acclimatization under identical conditions (Fonteno and McWilliams, 1978). Similar results were obtained by Pass and Hartley (1979) with three tropical foliage species under four light levels. All species displayed an increase in net $\mathrm{CO}_{2}$ uptake efficiency with a decrease in dark $\mathrm{CO}_{2}$ evolution (Fails et al., 1982a, 1982b; Fonteno and McWilliams, 1978; Pass and Hartley, 1979).

The objectives of this study were to determine the degree of acclimatization under simulated interior lighting conditions (SIL) of $L$. coccinia and $L$. rubra when compared with Ficus benjamina.

All cuttings were propagated between 8 Jan. and 15 Feb. 1986. Leaf/bud cuttings of L. coccinia and L. rubra were propagated in 1 peat : 1 vermiculite $(\mathrm{v} / \mathrm{v})$ with bottom heat and mist. Cuttings of $F$. benjamina consisting of three to five leaves were treated basally with $0.3 \% 1 \mathrm{H}$ - indole-3-butanoic acid (IBA) in talc and rooted in 2 peat : 1 perlite (v/v) with bottom heat and mist. All plants were grown under greenhouse full sun conditions and were repotted twice between the propagation date and 5 May 1986 resulting in 350 L. coccinia, 410 L. rubra, and 350 $F$. benjamina plants, all grown in 3-liter plastic pots.

A $3 \times 3 \times 3$ repeated measure factorial design experiment-three photosynthetic photon flux levels, three measurement dates and three species-was started in the greenhouse on 4 July 1986. Each photosynthetic photon flux light treatment was achieved by placing one layer or a combination of layers of silver foiled reflective cloth, $92 \%$ black polypropylene shade cloth, and $63 \%$ black polypropylene shade cloth to create treatments of $98.7 \%\left(0.26 \mathrm{~mol} \cdot \mathrm{m}^{-2} \cdot\right.$ day $\left.^{-1}\right)$ and $99.8 \%\left(0.09 \cdot \mathrm{mol} \cdot \mathrm{m}^{-2} \cdot \mathrm{day}^{-1}\right)$ shade, respectively, to simulate moderate to low light interior conditions. The control plants (full sun) were covered with one layer of $0.025-\mathrm{mm}$ thick clear polyethylene film to obtain air temperatures similar to the shade treatments. Cooling and air circulation in the shaded treatments were provided by greenhouse inflation blower fans. Light flux and temperature within each treatment were continuously recorded using $190 \mathrm{SB}$ quantum sensors (LICOR, Lincoln, Neb.) and copper-constantan thermocouples attached to a Campbell CR-7 data logger (Campbell Scientific, Logan, Utah). Plants for the experiments were selected for uniformity in plant height and width, leaf count, size, age, and canopy density and, in addition, for $F$. benjamina, number of growing points and number and angle of the branches. Each treatment consisted of four plants of each species. Photosynthetic and respiration rates were recorded with a portable infrared $\mathrm{CO}_{2}$ gas analyzer (ADC Corp., Hoddesdon, U.K.) on 4, 18, and 28 July 1986 for each plant while being kept in a growth chamber with controlled light (fluorescent/incandescent) and at $30 \pm 2 \mathrm{C}$. The portable leaf chamber (area $6.25 \mathrm{~cm}^{2}$ ), located $76 \mathrm{~cm}$ from the light source, was clamped onto the first fully developed leaf from the apex of the plant. Each leaf was subjected to six levels of photosynthetically active radiation of $125,80,44,11,4$, and $0 \mu \mathrm{mol} \cdot \mathrm{m}^{-2} \cdot \mathrm{s}^{-1}$ to obtain light compensation points $\left(\mathrm{LCP}\right.$; net $\mathrm{CO}_{2}$ uptake $=$ net $\mathrm{CO}_{2}$ evolution). Data were analyzed using linear regression methods to calculate light compensation points. Light compensation points were calculated by substituting $\mathrm{y}=0$ into each respective regression equation. Data were then analyzed using the General Linear Models procedure and Duncan's multiple range test.

Leea coccinia. Light compensation points for control plants remained fairly stable until day 25 , when a sharp decrease was recorded

Table 1. Light compensation points of Leea coccinia, L. rubra, and Ficus benjamina grown under three light levels in the greenhouse.

\begin{tabular}{|c|c|c|c|c|}
\hline \multirow[b]{3}{*}{ Species } & \multirow{3}{*}{$\begin{array}{l}\text { Shade } \\
\text { level } \\
(\%)^{2}\end{array}$} & \multicolumn{3}{|c|}{$\begin{array}{l}\text { Light compensation } \\
\text { point }\left(\mu \mathrm{mol} \cdot \mathrm{m}^{-2} \cdot \mathrm{s}^{-1}\right)\end{array}$} \\
\hline & & \multicolumn{3}{|c|}{ No. days } \\
\hline & & 0 & 14 & 25 \\
\hline Leea coccinia & $\begin{array}{c}0 \\
98.7 \\
99.8\end{array}$ & $\begin{array}{l}88.1 \\
88.1 \\
88.1\end{array}$ & $\begin{array}{l}73.1 \mathrm{a}^{y} \\
36.7 \mathrm{~b}^{27.5} \mathrm{~b}\end{array}$ & $\begin{array}{l}51.6 \mathrm{a} \\
21.3 \mathrm{~b} \\
33.6 \mathrm{~b}\end{array}$ \\
\hline $\begin{array}{l}\text { ignificance } \\
\text { Shade }\end{array}$ & & NA & $* *$ & 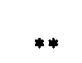 \\
\hline eea rubra & $\begin{array}{c}0 \\
98.7 \\
99.8\end{array}$ & $\begin{array}{l}83.8 \\
83.8 \\
83.8\end{array}$ & $\begin{array}{c}84.0 \mathrm{a} \\
-. \mathrm{x}^{-} \\
48.3 \mathrm{~b}\end{array}$ & $\begin{array}{l}67.1 \mathrm{a} \\
48.7 \mathrm{a} \\
24.5 \mathrm{~b}\end{array}$ \\
\hline $\begin{array}{l}\text { Significance } \\
\text { Shade }\end{array}$ & & NA & 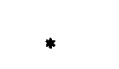 & $* *$ \\
\hline Ficus benjamina & $\begin{array}{c}0 \\
98.7 \\
99.8\end{array}$ & $\begin{array}{l}72.1 \\
72.1 \\
72.1\end{array}$ & $\begin{array}{r}75.3 \mathrm{a} \\
144.0 \mathrm{a} \\
162.6 \mathrm{a}\end{array}$ & $\begin{array}{l}69.6 \\
\text { Dead } \\
\text { Dead }\end{array}$ \\
\hline $\begin{array}{l}\text { Significance } \\
\text { Shade }\end{array}$ & & NA & NS & NA \\
\hline $\begin{array}{l}{ }^{2} 0 \%=15.74 \\
\text { mol'm-2.day } \\
{ }^{y} \text { Mean separat } \\
\text { Duncan's mult } \\
\text { xMissing plot; } \\
\text { closure. }\end{array}$ & an & 0 & 0.0 & $\begin{array}{l}0.09 \\
\text { sing }\end{array}$ \\
\hline
\end{tabular}

HorTSCIEnCe, Vol. 27(5), May 1992 
Table 2. Net photosynthesis and dark respiration of Leea coccinia, L. rubra, and Ficus benjamina, after 0,14 , and 25 days under three light levels in the greenhouse.

\begin{tabular}{|c|c|c|c|c|}
\hline \multirow[b]{2}{*}{ Species } & \multirow[b]{2}{*}{ No. days } & \multicolumn{3}{|c|}{ Shade level $(\%)^{2}$} \\
\hline & & 0 & 98.7 & 99.8 \\
\hline Leea coccinia $\mathrm{Pn}^{y}$ & $\begin{array}{r}0 \\
14 \\
25\end{array}$ & $\begin{array}{l}1.39 \mathrm{~b}^{x} \\
2.24 \mathrm{~b}^{2} \\
3.21 \mathrm{a}^{2}\end{array}$ & $\begin{array}{l}1.39 \mathrm{~b} \\
2.27 \mathrm{~b} \\
3.83\end{array}$ & $\begin{array}{l}1.39 \mathrm{~b} \\
3.52 \mathrm{a}\end{array}$ \\
\hline Significance, days & & $3.21 \mathrm{~d}$ & $3.03 \mathrm{a}$ & \\
\hline $\mathrm{Rd}^{\mathbf{w}}$ & $\begin{array}{r}0 \\
14 \\
25\end{array}$ & $\begin{array}{l}-3.91 \mathrm{~b} \\
-3.54 \mathrm{ab} \\
-2.75 \mathrm{a}\end{array}$ & $\begin{array}{l}-3.91 b \\
-1.30 \mathrm{a} \\
-1.02 \mathrm{a}\end{array}$ & $\begin{array}{l}-3.91 b \\
-1.17 a \\
-0.95 a\end{array}$ \\
\hline Significance, days & & NS & ${ }^{* *}$ & ** \\
\hline Leea rubra Pn & $\begin{array}{r}0 \\
14 \\
25\end{array}$ & $\begin{array}{l}1.39 \mathrm{a} \\
1.31 \mathrm{a} \\
1.75 \mathrm{a}\end{array}$ & $\begin{array}{l}1.39 \mathrm{a} \\
-\mathrm{v}^{\mathrm{v}} \\
1.86 \mathrm{a}\end{array}$ & $\begin{array}{l}1.39 \mathrm{a} \\
1.96 \mathrm{ab} \\
3.03 \mathrm{~b}\end{array}$ \\
\hline Significance, days & & NS & NS & $*$ \\
\hline $\mathrm{Rd}$ & $\begin{array}{r}0 \\
14\end{array}$ & $\begin{array}{l}-3.14 b \\
-2.88 b\end{array}$ & $-3.14 b$ & $\begin{array}{l}-3.14 \mathrm{~b} \\
-1.31 \mathrm{a}\end{array}$ \\
\hline Significance, days & 25 & $-2.28 \mathrm{a}$ & $-1.29 \mathrm{a}$ & $-1.01 \mathrm{a}$ \\
\hline Ficus benjamina $\mathrm{Pn}$ & $\begin{array}{r}0 \\
14 \\
25\end{array}$ & $\begin{array}{l}3.14 \mathrm{a} \\
2.61 \mathrm{a} \\
2.35 \mathrm{a}\end{array}$ & $\begin{array}{c}3.14 \mathrm{a} \\
-0.12 \mathrm{~b} \\
\text { Dead }\end{array}$ & $\begin{array}{c}3.14 \mathrm{a} \\
-0.21 \mathrm{~b} \\
\text { Dead }\end{array}$ \\
\hline Significance, days & & NS & $* *$ & $* *$ \\
\hline $\mathrm{Rd}$ & $\begin{array}{r}0 \\
14 \\
25\end{array}$ & $\begin{array}{l}-3.93 \mathrm{ab} \\
-4.36 \mathrm{~b} \\
-3.50 \mathrm{a}\end{array}$ & $\begin{array}{c}-3.93 \mathrm{a} \\
-1.20 \mathrm{~b} \\
\text { Dead }\end{array}$ & $\begin{array}{c}-3.93 \mathrm{a} \\
-1.01 \mathrm{~b} \\
\text { Dead }\end{array}$ \\
\hline Significance, days & & NS & $* *$ & $* *$ \\
\hline
\end{tabular}

${ }^{2} 0=15.74 \%, 98.7 \%=0.26,99.8 \%=0.09 \mathrm{~mol}^{-2} \cdot \mathrm{m}^{-1}{ }^{-1}$.

${ }^{y} \mathrm{mg} \mathrm{CO} / \mathrm{dm}^{2}$ per hour; measured at $125 \mu \mathrm{mol} \cdot \mathrm{m}^{-2} \cdot \mathrm{s}^{-1}$.

${ }^{x}$ Mean separation in columns by species using Duncan's multiple range tcst, $P>0.05$.

${ }^{\mathrm{w}} \mathrm{mg} \mathrm{CO} / 2 / \mathrm{dm}^{2}$ per hour; measured at $0 \mu \mathrm{mol} \cdot \mathrm{m}^{-2} \cdot \mathrm{s}^{-1}$.

"Missing plot; not measurable due to stomatal closure.

Ns,*,**Not significant or significant at $P=0.05$ or 0.01 , respectively.

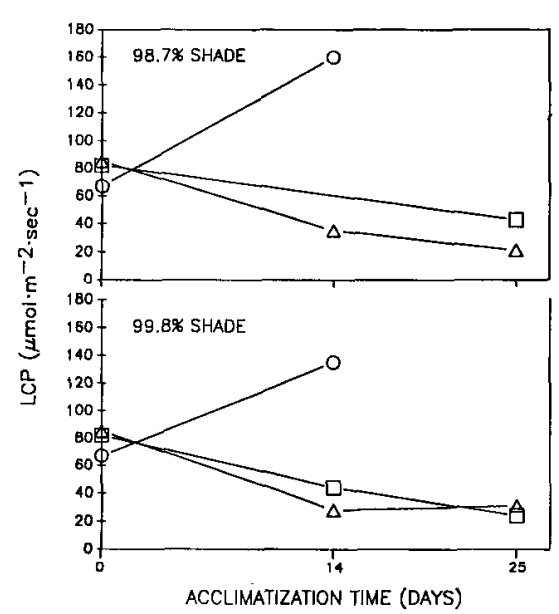

Fig. 1. Light acclimatization rates of Leea coccinia $(\triangle)$, L. rubra $(\square)$ and Ficus benjamina (O) grown under $98.7 \%\left(0.26 \mathrm{~mol} \cdot \mathrm{m}^{-2} \cdot\right.$ day $\left.^{-1}\right)$ (top) and $99.8 \%\left(0.09 \mathrm{~mol} \cdot \mathrm{m}^{-2} \cdot \mathrm{day}^{-1}\right)($ bottom) shade.

(Table 1). The reason for this change is unknown but may have been caused by several days of very cloudy weather resulting in a shading effect. Plants grown under $98.7 \%$ shade for 25 days exhibited a reduction in LCP of $76 \%$ over initial values, while those grown under $99.8 \%$ shade exhibited a reduction of $62 \%$ (Table 1). By 25 days, up take of $\mathrm{CO}_{2}$ had increased $276 \%$ for plants grown under $98.7 \%$ shade and $160 \%$ for those grown under $99.8 \%$ shade compared with initial values (Table 2). Respiration rates decreased by $74 \%$ over initial values for $98.7 \%$ shade plants and by $76 \%$ for plants grown points of plants in full sun remained fairly constant for the three measurement dates (Table 1). Plants in the $98.7 \%$ and $99.8 \%$ shade treatments began to drop mature green leaves, immature leaves, and growing points after only 5 days. At day 14, LCP for plants in the $98.7 \%$ shade group had increased $200 \%$, while for plants grown under $99.8 \%$ shade it had increased $226 \%$ compared with initial values (Table 1). We suspect that the increase was due to maintenance respiration costs exceeding photosynthetic capacity. After 25 days, responses could not be measured because the plants had died. Leaf drop of sun-grown $F$. benjamina in response to reduced light during acclimatization is well documented (Collard et al., 1977). Conover and Poole (1975) reported severe leaf drop when plants grown in full sun in Florida with no acclimatization were placed under $40 \%$ or $80 \%$ shade. Fails et al. (1982a), however, reported no deterioration in plant quality of $F$. benjamina when first grown in Virginia under full sun and then moved to $75 \%$ shade for 12 weeks. While the LCP for acclimatizing $F$. benjamina reported here were inconsistent with several previously reported results, the degree of shading we used was much greater than those used by others, making direct comparison inappropriate. The inability of the older leaves to compensate for the drastically reduced light intensity by increasing their photosynthetic efficiency in this study and high respiration costs may have resulted in the leaf drop, lack of regrowth, and the inability to acclimatize, as indicated by the pattern of LCP changes. Consequently, the LCP increased rather than declined (Fig. 1). Soil moisture content also may have been a contributing factor. Under reduced PPF, soil moisture is maintained through reduced evaporation and, indirectly, through reduced evapotranspiration as affected by leaf drop. Johnson et al. (1981) reported more leaf drop under simulated interior lighting conditions for $F$. benjamina plants previously watered at 3-day intervals than for plants watered at 6- or 9-day intervals.

Both $L$. coccinia and L. rubra displayed decreasing LCP with decreasing light. Respiration after 25 days, regardless of the degree of shading, was reduced a minimum of $74 \%$ and $59 \%$, respectively, for L. coccinia and $L$. rubra, while $\mathrm{CO}_{2}$ uptake increased a minimum of $65 \%$ and $34 \%$, respectively. In comparison, Fonteno and McWilliams (1978), reported a $50 \%$ to $70 \%$ reduction in dark $\mathrm{CO}_{2}$ evolution in each of four foliage species after 15 weeks of acclimatization. The ability of $L$. coccinia and $L$. rubra to acclimatize rapidly by lowering their LCP with minimum leaf abscission may have resulted in older leaves increasing their photosynthetic efficiency (Fails et al., 1982b; Pass and Hartley, 1979). Since both Leea spp. exhibited a continuing decrease in LCP after 25 days, the possibility exists for even further reductions in LCP over an extended time. The implication is that Leea may be able to be grown under light levels lower than those used in this study. 


\section{Literature Cited}

Boardman, N.K. 1975. Comparative photosynthesis of shade and sun plants. Annu. Rev. Plant Phys. 28:355-377.

Collard, R.C., J.N. Joiner, C.A. Conover, and D.B. McConnell. 1977. Influence of shade and fertilizer on light compensation point of Ficus benjamina L. J. Amer. Soc. Hort. Sci. 102(4):447-449.

Conover, C.A. and R.T. Poole. 1975. Acclimatization of tropical trees for interior use. HortScience 10(6):600-601.

Fails, B.S., A.J. Lewis, and J.A. Barden. 1982a.
Anatomy and morphology of sun- and shadegrown Ficus benjamina. J. Amer. Soc. Hort. Sci. 107(5):754-757.

Fails, B.S., A.J. Lewis, and J.A. Barden. 1982b. Light acclimatization Potential of Ficus benjamina. J. Amer. Soc. Hort. Sci. 107(5):762766.

Fonteno, W.C. and E.L. McWilliams. 1978. Light compensation points and acclimatization of four tropical foliage plants. J. Amer. Soc. Hort. Sci. 103(1):52-56.

Johnson, C.R., D.L. Ingram, and J.E. Barrett. 1981. Effects of irrigation frequency on growth, transpiration and acclimatization of Ficus benjamina L. HortScience 16(1):80-81.

Larson, R. 1979. The tolerance of ornamental foliage plants to low light intensities. Swedish J. Agr. 9:169-172.

Liberty Hyde Bailey Hortorium. 1977. Hortus third: A concise dictionary of plants cultivated in the United States and Canada. Macmillan, New York. p. 643-644.

Pass, R.G. and D.E. Hartley. 1979. Net photosynthesis of three foliage plants under low irradiation levels. J. Amer. Soc. Hort. Sci. 104(6):745-748. 